\title{
Developmental defects of enamel, sociodemographic aspects and systemic diseases: Is
}

\section{there association?}

\author{
Defeitos de desenvolvimento do esmalte, aspectos sociodemográficos e doenças sistêmicas: Existe
} associação?

Defectos del desarrollo del esmalte, aspectos sociodemográficos y enfermedades sistémicas: ¿Existe asociación?

Glacy Félix de Mendonça Zina

ORCID: https://orcid.org/0000-0002-8849-0504 Centro Universitário de Várzea Grande, Brazil E-mail: gzina@gmail.com

Mariano Martinez Espinosa ORCID: https://orcid.org/0000-0002-0461-5673 Universidade Federal de Mato Grosso, Brazil E-mail: mespinosa@usmt.edu.br

Caleb Shitsuka

ORCID: https://orcid.org/0000-0002-9813-0457 Universidade Brasil, Brazil E-mail: cashitsuka@gmail.com

José Carlos Pettorossi Imparato ORCID: https://orcid.org/0000-0002-1990-2851 São Leopoldo Mandic, Brazil E-mail: jimparato@usp.br Danilo Antônio Duarte

ORCID: https://orcid.org/0000-0002-2291-5434 São Leopoldo Mandic, Brazil

E-mail: danilo.ant.duarte@gmail.com

\begin{abstract}
Objective: Evaluate the prevalence of developmental defects of enamel (DDE) in permanent molars and its association with sociodemographic characteristics and systemic conditions in children treated at the paediatric dentistry clinic of private dental school. Material and Methods: The sample consisted of 706 medical records of children aged 8 to 12 years of both sexes, treated between 2004 and 2017. The inclusion criteria included the presence of the first 4 permanent molars, absence of syndromes related to enamel malformations and dentoalveolar trauma in the first 3 years of life and complete medical records. The dependent variable (hypomineralization/hypoplasia) and the independent variables (sociodemographic and health variables) were collected and evaluated using descriptive analysis, association tests (chi-square) and logistic regression, at a significance level of 5\%. Results: The prevalence of DDE in the first permanent molars was 55.95\%, with no association with sociodemographic characteristics. Conclusions: The association of DDE in the first 4 permanent molars with the independent variables such as caesarean, forceps or preterm delivery and systemic diseases until 3 years of age were statistically significant.
\end{abstract}

Keywords: Child health; Dental enamel hypoplasia; Epidemiology; Pediatric dentistry.

\section{Resumo}

Objetivo: Avaliar a prevalência de defeitos de desenvolvimento do esmalte (DDE) em molares permanentes e sua associação com características sociodemográficas e condições sistêmicas em crianças atendidas na clínica de Odontopediatria de uma Faculdade de Odontologia particular. Material e Métodos: A amostra foi composta por 706 prontuários de crianças de 8 a 12 anos de ambos os sexos, atendidas entre 2004 e 2017. Os critérios de inclusão incluíram a presença dos 4 primeiros molares permanentes, ausência de síndromes relacionadas a malformações de esmalte e trauma dentoalveolar nos primeiros 3 anos de vida e ter o prontuário completo. A variável dependente (hipomineralização / hipoplasia) e as variáveis independentes (variáveis sociodemográficas e de saúde) foram coletadas e avaliadas por meio de análise descritiva, testes de associação (qui-quadrado) e regressão logística, com nível de significância de 5\%. Resultados: A prevalência de DDE nos primeiros molares permanentes foi de 55,95\%, sem associação com características sociodemográficas. Conclusões: A associação de DDE nos 4 primeiros molares 
permanentes com as variáveis independentes como cesárea, fórceps ou parto prematuro e doenças sistêmicas até os 3 anos de idade foi estatisticamente significativa.

Palavras-chave: Saúde da criança; Hipoplasia do esmalte dentário; Epidemiologia; Odontopediatria.

\begin{abstract}
Resumen
Objetivo: Evaluar la prevalencia de defectos del desarrollo del esmalte (DDE) en molares permanentes y su asociación con características sociodemográficas y condiciones sistémicas en niños atendidos en la clínica de odontopediatría de la facultad de odontología privada. Material y Métodos: La muestra estuvo compuesta por 706 historias clínicas de niños de 8 a 12 años de ambos sexos, tratados entre 2004 y 2017. Los criterios de inclusión incluyeron la presencia de los primeros 4 molares permanentes, ausencia de síndromes relacionados con malformaciones del esmalte y trauma dentoalveolares en los primeros 3 años de vida y registros médicos completos. La variable dependiente (hipomineralización / hipoplasia) y las independientes (variables sociodemográficas y de salud) fueron recolectadas y evaluadas mediante análisis descriptivo, pruebas de asociación (chi-cuadrado) y regresión logística, a un nivel de significancia del 5\%. Resultados: La prevalencia de DDE en los primeros molares permanentes fue del 55,95\%, sin asociación con características sociodemográficas. Conclusiones: La asociación de DDE en los primeros 4 molares permanentes con las variables independientes como cesárea, fórceps o parto pretérmino y enfermedades sistémicas hasta los 3 años de edad fue estadísticamente significativa.
\end{abstract}

Palabras clave: Salud del niño; Hipoplasia del esmalte dental; Epidemiología; Odontología pediátrica.

\title{
1. Introduction
}

Developmental defects of enamel (DDE) in permanent teeth is usually caused by systemic and environmental factors. DDE is the result of disturbance of the developing tooth germ. It may manifest as changes in enamel quality (hypomineralization) or quantity (hypoplasia), significantly affecting oral health, aesthetics, tooth sensitivity and occlusal dysfunction in children (Arrow, 2008). When referring to DDE, a clinical entity called molar-incisor hypomineralization (MIH) should be mentioned. MIH is characterized as a qualitative defect, presenting an opacity caused by an abnormality in the translucency of dental enamel, which may have a white, yellowish, cream or brownish colour but an intact surface with normal thickness. It affects, in a variable manner, the first permanent molars and incisors (Weerheijm, Jalevik \& Alaluusua, 2001; Jereminas et al., 2016).

Due to the complexity of the signs and symptoms, DDE and MIH predispose teeth to caries in childhood and the need for treatment. Treatment is not always successful because the abnormal enamel structure leads to anaesthesia difficulties and difficulty regarding adhesion between the restorative material and the affected enamel (Arrow, 2008). The association between caries in deciduous teeth and the presence of demarcated opacities and hypoplasia in their permanent successors was documented in a cohort of children living in a non-fluoridated area in southern China (Lo, Zheng \& King, 2003). This is a serious clinical problem for children and of great concern to paediatric dentists and/or general practitioners, hence the importance of identifying the factors associated with the reported abnormality and the consequent risk factor for dental caries (Opydo-Szymaczeka et al., 2018).

Studies show that proteinases from ameloblasts degrade enamel proteins as mineralization occurs, with deposition of calcium and phosphorus. This deposition in the form of crystals grows in increments, and because it does not maintain a relationship with the cells that form it, enamel does not have the capacity for neoformation or remodelling. Thus, enamel functions as a biological marker of environmental and genetic information and/or disturbances experienced during its development (Ryynanen et al., 2014).

The prevalence of DDE varies according to the region studied. In southern Brazil (Vargas-Ferreira et al., 2018), of 1,206 children aged 8 to 12 years old, the DDE prevalence was $64.0 \%$, and the main enamel defects were diffuse opacities (34.75\%), demarcated opacities (29.5\%) and hypoplasia (3.7\%). In an evaluation of 511 children in Australia (Arrow, 2008), $71 \%$ of permanent molars were affected; $47 \%$ of the defects were diffuse white opacities, and $22 \%$ were demarcated opacities. In Spain, a high prevalence was also found in both deciduous teeth $(40.2 \%)$ and permanent teeth $(52 \%)$, with a significant 
difference between sexes (Robles et al., 2013). Moreover, with age, there is a predominance of structural defects over opacities (Opydo-Szymaczeka et al., 2018).

In an attempt to clarify the causal factor, in Denmark, researchers found a correlation between the use of anti-epileptic medication during pregnancy and DDE in deciduous and permanent dentition (Jacobsen et al., 2013). These same authors, through a systematic review, concluded that there was an association between prematurity and developmental enamel defects in deciduous dentition; however, because they did not find enough available and reliable studies, the association in permanent dentition was of lower intensity (Jacobsen et al., 2014).

The sociodemographic variables maternal education and household income were not associated with MIH in 1181 Brazilian schoolchildren aged 8 and 9 years old. However, the independent variables prenatal, perinatal, and postnatal care, oral health, dental caries in permanent teeth, DDE in second deciduous molars and asthma and/or bronchitis in the first 4 years of life were associated with MIH (Tourino et al., 2016).

Despite the reliability of studies being compromised by methodologies, confounding factors, details and consistency, a systematic review showed that diseases in early childhood, mainly fever, asthma and pneumonia, were considered aetiological factors for MIH. Despite a limited number of studies, the study also concluded that factors such as the use of medications during pregnancy, prematurity and complications during delivery were also associated with MIH (Silva et al., 2016).

When investigating pre, peri and post natal risk factors in 282 children aged 7 to 8 years old in Thailand, caesarean section, complications during delivery and health problems during the first 3 years of life were risk factors for DDE/MIH, but no association was found between preterm delivery and MIH (Pitiphat et al., 2014).

The association with type of childhood illness and medication received in the first 3 years of life was not statistically significant (Arrow, 2009). However, in Pakistan, through an evaluation of 376 children of both sexes with a history of frequent use of antibiotics such as penicillin or cephalosporin in early childhood, a positive association with DDE (hypomineralization) was found (Tariq et al., 2014). Corroborating these clinical findings, an in vitro study of rat molars showed that the use of amoxicillin significantly affected enamel development, which was found to be porous, suggesting delayed or disturbed secretion and/or mineralization; however, the effect was dose-dependent (Sahlberg et al., 2013).

Due to differences in the methodologies used in the studies evaluated, a literature review found no relationship between DDE/MIH and medication (Serna et al., 2016). Regarding medication used for asthma, the authors found no association with DDE, but there was a correlation between DDE and disease severity because ameloblasts are highly sensitive to oxygen supply. Corroborating this finding and considering memory bias, due to retrospective data collection, the factors associated with DDE were investigated through a prospective cohort study. Among the aetiological factors considered, only children who experienced severe diseases before 3 years of age were 7.89 times more likely to be affected by DDE in permanent molars (Wong et al., 2014).

Considering systemic problems, high temperature $\left(39^{\circ} \mathrm{C}\right)$ can impair or delay enamel development in the molars of rats by negatively affecting the genes that regulate tooth development, especially enamel development (Ryynanen et al., 2014). In addition, cardiac problems, craniofacial development defects, including cleft palate and abnormal dental development, were found in epidemiological studies with humans who developed hyperthermia during pregnancy (Edwards, 2006).

DDE is induced and regulated by factors such as genetics and the environment. Because dioxin in polluted areas has a strong impact on tooth health and development, to identify its effect on the prevalence of DDE (Ngoc et al., 2018), 2200 adults were evaluated in 2015 by comparing 2 regions in Vietnam, one affected and another not affected by dioxin. In general, the prevalence of DDE in the region affected by dioxin was 2,2 times higher than that in the non-affected region. It has been previously reported that in the first years of life (Hölttä et al., 2001), the first permanent molars and incisors have a higher risk 
of developing hypoplasia and hypomineralization when exposed to dioxin through foods such as milk, dairy products, meat and fish (Laisi et al., 2008). That was confirmed in an in vitro study that, using immune histochemical analysis of rat tooth germ (Salmela et al., 2011), observed disturbances in pre dentin secretion and enamel matrix mineralization caused by the combined effect of sodium fluoride $(\mathrm{NaF})$ and tetrachlorodibenzo-p-dioxin (TCDD). In addition to these substances, an abnormal accumulation of organic material was also found in the enamel of the erupting teeth of rats when using bisphenol $\mathrm{A}$ (BPA) (Jedeon et al., 2013).

Knowledge and prevention of DDE requires a substantial understanding of the aetiological factors. Therefore, the objective of this study is to evaluate the association between DDE in permanent molars and the social, demographic and health characteristics of this severe condition in the population treated at a clinical school, with a direct impact on the graduate programme of the institution and the quality of life of this population.

\section{Methodology}

This is a retrospective cross-sectional study conducted using the medical records from the dentistry clinic of UNIVAG - Várzea Grande University Centre, state of Mato Grosso, Brazil. This municipality has an estimated population of 282,009 in habitants in 2018 and is located in the Centre-West region of the country (IBGE, 2015). The graduate programme in dentistry was established at this institution in 1999.

After obtaining authorization for the study and for access to the archive of the higher education institution, 706 medical records were evaluated. The population was composed of male and female children, aged 8 to 12 years, from the state of Mato Grosso, with the first 4 permanent molars in the oral cavity; without syndromes associated with tooth enamel malformations and dentoalveolar trauma in the first 3 years of life; with a consent form for the diagnosis and/or execution of the treatment plan signed by the parents/guardians; and with a complete clinical record in the Paediatric Dentistry Clinic. The survey included records from 2004, the year when the Paediatric Dentistry specialty was implemented at the institution, until 2017.

The records examined in the present study were completed by students in the seventh semester of the dentistry graduate programme at UNIVAG- Várzea Grande University Centre, Paediatric Dentistry Clinic. The patients and their respective parents, mostly mothers, visited the clinic with personal documents and a child health record. After completing a targeted clinical interview, a dental physical examination was performed at the dental clinic using personal protective equipment, sterilized and individualized materials, and clean, dry and well-illuminated teeth. Students who participated in the data collection were trained prior to the clinical activity, which was standardized through a calibration report based on the modified DDE (FDI, 1992), under the responsibility, supervision and direction of the professors of that discipline and led by the researcher.

In the present study, the dependent variable or outcome was hypomineralization/hypoplasia in the first permanent molars. The independent variables were sociodemographic and health variables. The sociodemographic variables were sex (male and female); age (divided into 5 age groups in years - 8, 9, 10, 11 and 12 years); place of origin (Cuiabá, Várzea Grande and other municipalities of Mato Grosso); and maternal education (primary, secondary or higher education). The health variables were pregnancy (normal and abnormal); type of delivery (caesarean section, forceps, preterm, normal); breastfed up to 6 months (yes or no); systemic diseases in the first 3 years of life (yes or no); history of use of medication (yes or no); hospitalization in the first 3 years of life (yes or no); tooth eruption (before 8 months, at 8 months or after 8 months); oral habit (with or without habit); and breathing (altered or preferably nasal).

This study presented minimal risks for the selected individuals, according to the CNS Resolution 196/96, as it used secondary data collected from medical records. The benefits of the study include that fact that knowledge of the prevalence of 
hypomineralization/hypoplasia and its explanatory factors may improve the painful and aesthetic processes in the daily life of children aged 8 to twelve years who seek dental care at UNIVAG - Várzea Grande University Centre. In addition, the faculty and students of the aforementioned educational institution will be provided access to the results of the study.

Data were collected by the researcher in a digital database in Excel ${ }^{\circledR}$ format, and the statistical analysis was conducted using SPSS software (version 20.0 SPSS Inc., Chicago, IL, USA). In the statistical analysis, descriptive and inferential statistics were applied. In the descriptive analysis, absolute and relative frequencies (proportions) were used, and in the inferential analysis, a bivariate and multivariate analysis was applied. In the bivariate analysis, the chi-squared test and crude prevalence ratio with their respective $95 \%$ confidence intervals were used to determine the associations between the dependent variable and the independent variables. In the multivariate analysis, adjusted prevalence ratios were obtained using Poisson multiple regression models, with respective $95 \%$ confidence intervals; all variables with $\mathrm{p}<0.20$ were included in the models, with the final model containing only the variables with a $\mathrm{p}<0.05$.

This study was approved by the Research Ethics Committee of the São Leopoldo Mandic Dentistry Research Centre (protocol 2,155,834).

\section{Results}

A total of 706 medical records catalogued in the archive of the Paediatric Dentistry Clinic of UNIVAG - Várzea Grande University Centre that met the inclusion criteria were selected for analysis of the first permanent molars. Tables 1, 2 and 3 present demographic, socioeconomic, health and maternal variables, with their respective prevalence and 95\% confidence interval.

Table 1. Demographic and socioeconomic characteristics of 706 patients treated at the Pediatric Dentistry Clinic of UNIVAGCentro Universitário de Várzea Grande, with their respective prevalence and 95\% confidence interval, Cuiabá - MT, 2017.

\begin{tabular}{lccc}
\hline Characteristics & N & \% & IC 95\% \\
\hline Sex & & & \\
Male & 367 & 51,98 & $(48,22 ; 55,72)$ \\
Female & 339 & 48,02 & $(44,28 ; 51,78)$ \\
Total & 706 & 100 & - \\
Age & & & \\
8 years & 395 & 55,95 & $(52,20 ; 59,65)$ \\
9 years & 147 & 20,82 & $(17,88 ; 24,01)$ \\
10 years & 91 & 12,89 & $(10,51 ; 15,59)$ \\
11 years & 38 & 5,38 & $(3,84 ; 7,31)$ \\
12 years & 35 & 4,96 & $(3,48 ; 6,83)$ \\
Total & 706 & 100 & - \\
Naturalness & & & \\
Cuiabá & 462 & 65,44 & $(61,80 ; 68,95)$ \\
Other municipalities of MT & 244 & 34,56 & $(31,05 ; 38,20)$ \\
Total & 706 & 100 & - \\
Maternal Education & & & $(42,73 ; 50,22)$ \\
Elementary School & 328 & 46,46 & $(43,71 ; 51,21)$ \\
High school & 335 & 47,45 & - \\
Higher education & 43 & 6,09 & $(4,46)$ \\
Total & 706 & 100 & \\
\hline
\end{tabular}


n: Absolute frequency of patients by category. \%: Percentage of patients by category. 95\% CI: $95 \%$ confidence interval. Source: Authors.

Table 1 shows a predominance of male children (51.98\%), aged 8 years (55.95\%), from Cuiabá (65.44\%), whose mothers had secondary education $(47.45 \%)$.

Table 2. Health characteristics of 706 patients and their mother attended at the Pediatric Dentistry Clinic of UNIVAG-Centro Universitário de Várzea Grande, with their respective prevalence and 95\% confidence interval, Cuiabá - MT, 2017.

\begin{tabular}{|c|c|c|c|}
\hline Characteristics & $\mathbf{n}$ & $\%$ & IC $95 \%$ \\
\hline \multicolumn{4}{|l|}{ Gestation } \\
\hline Not normal & 86 & 12,18 & $(9,86 ; 14,82)$ \\
\hline Normal & 620 & 87,82 & $(85,17 ; 90,14)$ \\
\hline Total & 706 & 100 & - \\
\hline \multicolumn{4}{|l|}{ Type of delivery } \\
\hline $\begin{array}{l}\text { Caesarean section, forceps and } \\
\text { premature }\end{array}$ & 373 & 52,83 & $(49,07 ; 56,57)$ \\
\hline Normal & 333 & 47,17 & $(43,43 ; 50,93)$ \\
\hline Total & 706 & 100 & - \\
\hline \multicolumn{4}{|l|}{ Breastfeeding up to 6 months } \\
\hline Not & 228 & 32,30 & $(28,85 ; 35,88)$ \\
\hline Yes & 478 & 67,70 & $(64,17 ; 71,14)$ \\
\hline Total & 706 & 100 & - \\
\hline \multicolumn{4}{|l|}{ Systemic diseases up to 3 years } \\
\hline Yes & 437 & 61,90 & $(58,20 ; 65,49)$ \\
\hline Not & 269 & 38,10 & $(34,51 ; 41,80)$ \\
\hline Total & 706 & 100 & - \\
\hline \multicolumn{4}{|l|}{ Previous drug use } \\
\hline Yes & 420 & 59,49 & $(55,76 ; 63,14)$ \\
\hline Not & 286 & 40,51 & $(36,86 ; 44,24)$ \\
\hline Total & 706 & 100 & - \\
\hline \multicolumn{4}{|l|}{ Internment up to 3 years } \\
\hline Yes & 209 & 29,60 & $(26,26 ; 33,12)$ \\
\hline Not & 497 & 70,40 & $(66,88 ; 73,74)$ \\
\hline Total & 706 & 100 & - \\
\hline \multicolumn{4}{|l|}{ Teeth eruption } \\
\hline$\leq 8$ months & 527 & 74,65 & $(71,27 ; 77,82)$ \\
\hline$>8$ months & 179 & 25,35 & $(22,18 ; 28,73)$ \\
\hline Total & 706 & 100 & - \\
\hline \multicolumn{4}{|l|}{ Oral habit } \\
\hline With habit & 468 & 66,29 & $(62,67 ; 69,77)$ \\
\hline Without habit & 238 & 33,71 & $(30,23 ; 37,33)$ \\
\hline Total & 706 & 100 & - \\
\hline \multicolumn{4}{|l|}{ Breath } \\
\hline Changed & 288 & 40,79 & $(37,14 ; 44,52)$ \\
\hline Nasal Preference & 418 & 59,21 & $(55,48 ; 62,86)$ \\
\hline Total & 706 & 100 & - \\
\hline
\end{tabular}


n: Absolute frequency of patients by category. \%: Percentage of patients by category. 95\% CI: 95\% confidence interval. Source: Authors.

Regarding health aspects, there was a predominance of normal pregnancies (87.82); caesarean section, forceps or preterm deliveries (52.83\%) and breastfeeding for up to6 months $(67.70 \%)$. In the first 3 years of life, of the 706 children evaluated, 61.90\% had systemic diseases (pneumonia, jaundice, malnutrition, anaemia, chicken pox, bronchitis, measles, reflux, seizures, dengue fever, fainting, chickenpox, chicken pox, hepatitis, diabetes, asthma, allergic rhinitis); 59.49\% used medication (antibiotics, analgesics, anti-inflammatories, antipyretics, syrups, antiallergics, anticonvulsants); and 70.40\% were not hospitalized. Additionally, there was a predominance of tooth eruption before 8 months (74.65\%); 66.29\% had harmful oral habits (finger sucking, pacifiers, biting objects, lip biting, nail biting, bruxism), and there was a predominance of nasal breathing $(59.21 \%)$, as shown in Table 2 .

Table 3. Characteristics of teeth with and without hypomineralization / hypoplasia of 706 patients treated at the Pediatric Dentistry Clinic of UNIVAG-Centro Universitário de Várzea Grande, with their respective prevalence and 95\% confidence interval, Cuiabá - MT, 2017.

\begin{tabular}{lccc}
\hline Characteristics & n & \% & IC 95\% \\
\hline Tooth 16 & & & \\
With hypomineralization / hypoplasia & 336 & 47,59 & $(43,85 ; 51,35)$ \\
No hypomineralization / hypoplasia & 370 & 52,41 & $(48,65 ; 56,15)$ \\
Total & 706 & 100 & - \\
Tooth 26 & & & \\
With hypomineralization / hypoplasia & 329 & 46,60 & $(42,87 ; 50,36)$ \\
No hypomineralization / hypoplasia & 377 & 53,40 & $(49,64 ; 57,13)$ \\
Total & 706 & 100 & - \\
Tooth 36 & & & \\
With hypomineralization / hypoplasia & 276 & 39,09 & $(35,48 ; 42,80)$ \\
No hypomineralization / hypoplasia & 430 & 60,91 & $(57,20 ; 64,52)$ \\
Total & 706 & 100 & - \\
Tooth 46 & & & $(41,33 ; 48,80)$ \\
With hypomineralization / hypoplasia & 318 & 45,04 & $(51,20 ; 58,67)$ \\
No hypomineralization / hypoplasia & 388 & 54,96 & - \\
Total & 706 & 100 & $(52,20 ; 59,65)$ \\
G4 & & & $(40,35 ; 47,80)$ \\
With hypomineralization / hypoplasia & 395 & 55,95 & - \\
No hypomineralization / hypoplasia & 311 & 44,05 & \\
Total & 706 & 100 & \\
\hline
\end{tabular}

n: Absolute frequency of patients by category. \%: Percentage of patients by category. 95\% CI: $95 \%$ confidence interval. Source: Authors.

Involvement of the first 4 permanent molars, especially teeth 36 and 46, with hypoplasia/hypomineralization was statistically significant when compared to the involvement of other teeth with hypoplasia/hypomineralization (Table 3). 
Table 4. Association between hypomineralization / hypoplasia of teeth G4 (teeth 16, 26, 36 and 46) and socio-demographic characteristics of 706 patients and mother attended at the Pediatric Dentistry Clinic of UNIVAG-Centro Universitário de Várzea Grande, with their respective reasons for gross prevalence, 95\% confidence interval and p values, Cuiabá - MT, 2017.

\begin{tabular}{|c|c|c|c|c|c|}
\hline \multirow[t]{2}{*}{ Characteristics } & \multicolumn{2}{|c|}{$\begin{array}{c}\text { Hypomineralization / } \\
\text { hypoplasia }\end{array}$} & \multirow[t]{2}{*}{$\mathbf{R P}_{\mathbf{b}}$} & \multirow[t]{2}{*}{ IC $95 \%$} & \multirow[t]{2}{*}{$\mathbf{p}$} \\
\hline & With & No & & & \\
\hline \multicolumn{6}{|l|}{ Sex } \\
\hline Male & 210 & 157 & 1,05 & $(0,92 ; 1,20)$ & 0,479 \\
\hline Female & 185 & 154 & 1,00 & - & - \\
\hline \multicolumn{6}{|l|}{ Age } \\
\hline $11-12$ years & 48 & 25 & 1,15 & $(0,96 ; 1,39)$ & 0,162 \\
\hline $09-10$ years & 122 & 116 & 0,90 & $(0,77 ; 1,05)$ & 0,163 \\
\hline 8 years & 225 & 170 & 1,00 & - & - \\
\hline \multicolumn{6}{|l|}{ Naturalness } \\
\hline Cuiaba & 268 & 194 & 1,11 & $(0,97 ; 1,29)$ & 0,129 \\
\hline Other municipalities of MT & 127 & 117 & 1,00 & - & - \\
\hline \multicolumn{6}{|l|}{ Maternal Education } \\
\hline Elementary School & 184 & 144 & 1,15 & $(0,83 ; 1,58)$ & 0,368 \\
\hline High school & 190 & 145 & 1,16 & $(0,84 ; 1,60)$ & 0,327 \\
\hline Higher education & 21 & 22 & 1,00 & - & - \\
\hline
\end{tabular}

$\mathbf{R P}_{\mathrm{b}}$ : Crude prevalence ratio. $\mathbf{9 5 \%}$ CI: $95 \%$ confidence interval. p: Chi-square test p value, significant values highlighted in bold at the 5\% level. Source: Authors. 
Table 5. Association between hypomineralization / hypoplasia of teeth G4 (teeth 16, 26, 36 and 46) and health characteristics of 706 patients and mother attended at the Pediatric Dentistry Clinic of UNIVAG-Centro Universitário de Várzea Grande, with their respective reasons for gross prevalence, 95\% confidence interval and p values, Cuiabá - MT, 2017.

\begin{tabular}{|c|c|c|c|c|c|}
\hline \multirow[t]{2}{*}{ Characteristics } & \multicolumn{2}{|c|}{$\begin{array}{c}\text { Hypomineralization / } \\
\text { hypoplasia }\end{array}$} & \multirow[t]{2}{*}{$\mathbf{R P}_{\mathbf{b}}$} & \multirow[t]{2}{*}{ IC $95 \%$} & \multirow{2}{*}{$\mathbf{p}$} \\
\hline & With & No & & & \\
\hline \multicolumn{6}{|l|}{ Gestation } \\
\hline Not normal & 52 & 34 & 1,09 & $(0,91 ; 1,32)$ & 0,368 \\
\hline Normal & 343 & 277 & 1,00 & - & - \\
\hline \multicolumn{6}{|l|}{ Type of delivery } \\
\hline $\begin{array}{l}\text { Caesarean section, forceps and } \\
\text { premature }\end{array}$ & 195 & 178 & 0,87 & $(0,76 ; 0,98)$ & $\mathbf{0 , 0 3 8}$ \\
\hline Normal & 200 & 133 & 1,00 & - & - \\
\hline \multicolumn{6}{|l|}{ Breastfeeding up to 6 months } \\
\hline Not & 120 & 108 & 0,92 & $(0,79 ; 1,06)$ & 0,220 \\
\hline Yes & 275 & 203 & 1,00 & - & - \\
\hline \multicolumn{6}{|l|}{ Systemic diseases up to 3 years } \\
\hline Yes & 261 & 176 & 1,20 & $(1,04 ; 1,38)$ & $\mathbf{0 , 0 1 0}$ \\
\hline Not & 134 & 135 & 1,00 & - & - \\
\hline \multicolumn{6}{|l|}{ Previous drug use } \\
\hline Yes & 246 & 174 & 1,12 & $(0,98 ; 1,29)$ & 0,089 \\
\hline Not & 149 & 137 & 1,00 & - & - \\
\hline \multicolumn{6}{|l|}{ Internment up to 3 years } \\
\hline Yes & 129 & 80 & 1,15 & $(1,02 ; 1,32)$ & 0,045 \\
\hline Not & 266 & 231 & 1,00 & - & - \\
\hline \multicolumn{6}{|l|}{ Teeth eruption } \\
\hline$\leq 8$ months & 293 & 234 & 0,99 & $(0,86 ; 1,14)$ & 0,747 \\
\hline$>8$ months & 102 & 77 & 1,00 & - & - \\
\hline \multicolumn{6}{|l|}{ Oral habit } \\
\hline With habit & 261 & 207 & 0,99 & $(0,86 ; 1,14)$ & 0,893 \\
\hline Without habit & 134 & 104 & 1,00 & - & - \\
\hline \multicolumn{6}{|l|}{ Breath } \\
\hline Changed & 164 & 124 & 1,03 & $(0,90 ; 1,18)$ & 0,658 \\
\hline Nasal Preference & 231 & 188 & 1,00 & - & - \\
\hline
\end{tabular}

$\mathbf{R P}_{\mathbf{b}}$ : Crude prevalence ratio. 95\% CI: 95\% confidence interval. p: Chi-square test p value, significant values highlighted in bold at 5\% level. Source: Authors. 
Table 4 shows the non-associations between hypomineralization/hypoplasia in the first permanent molars and sociodemographic characteristics. Table 5 shows the associations between this response variable and the health variables, where type of delivery ( $\mathrm{p}<0.038)$, systemic diseases $(\mathrm{p}<0.010)$ and hospitalization in the first 3 years of life $(\mathrm{p}<0.045)$ were statistically significant.

Table 6. Final Poisson multiple regression model of the variables associated with G4 teeth (teeth 16, 26, 36 and 46) with hypomineralization / hypoplasia of 706 patients and mother attended at the Pediatric Dentistry Clinic of UNIVAG-Centro Universitário de Várzea Grande, with their adjusted adjusted prevalence ratios, 95\% confidence interval and p values, Cuiabá MT, 2017.

\begin{tabular}{lccc}
\hline Variables / Categories & RP & IC $(95 \%)$ & P value \\
$\begin{array}{l}\text { Type of delivery } \\
\text { Caesarean section, forceps and } \\
\text { premature }\end{array}$ & 0,86 & $(0,76 ; 0,98)$ & $\mathbf{0 , 0 2 8}$ \\
Normal & 1,00 & - & - \\
& & & \\
Systemic diseases up to 3 years & 1,21 & $(1,05 ; 1,39)$ & $\mathbf{0 , 0 1 0}$ \\
Yes & 1,00 & - & - \\
Not & & \\
\hline
\end{tabular}

CI95\%: 95\% confidence interval; RPa: prevalence ratio adjusted by the Poisson regression model. P value: chi-square test. Source: Authors.

Table 6 shows the factors associated with the outcome that demonstrated statistical significance, fitted by the Poisson multiple regression model. In this situation, type of delivery was shown to be a protective factor $(\mathrm{PR}=0.86)$, and systemic disease in the first 3 years of life was a risk factor $(P R=1.21)$.

\section{Discussion}

The decision to develop the present study was, of course, preceded by extensive reading and studies, considering a relative plausibility in associating enamel defects caused by disturbances of systemic, local and even environmental origin, using clinical records as an evaluation tool, which is conceptually accepted as a multifunctional document in the health area.

It is not difficult to recognize that if this method facilitates a diagnosis or provides some indication of the aetiology of enamel defects, it could be used as another option, both at the level of public health and in private practice. That said, the development of this project, which aims to be a public health research, education and social intervention project, is justified, given that health is an essential condition for human happiness and quality of life.

Using bivariate and multivariate analyses, this study was designed to compare risk factors in children with and without DDE in the first permanent molars.

The study site, UNIVAG -University Centre, is located in the city of Várzea Grande, with an estimated population of 282,009 inhabitants in 2018. Fluoride is not added to the public water supply system in this city. Close to Cuiabá, capital of the state of Mato Grosso, the Paediatric Dentistry Clinic of UNIVAG effectively serves the community of Bairro Cristo Rei, a region considered to be a low-income population, in addition to Cuiabá and other cities in the state (IBGE, 2015).

The sample extracted from the archives of this institution dates from the implementation of the Dentistry graduate course. The tool used in the study, the medical record, was built during the teaching-learning process with training and 
calibration of the students for completing medical records, coordinated by a team of teachers and led by the researcher. The vast majority of interviews involved mothers; all other interviewees were conducted with the main caregiver during the first 3 years of the child's life. Health information and supporting documents were collected before performing the intraoral physical examination. The examiners' improvement in the knowledge about and interpretation of the examination criteria was observed in a homogeneous and consistent way through the analysis of these records (FDI, 1992).

A medical record constitutes a document of extreme relevance, being used for diagnosis but also for education, prevention and treatment strategies, as in the case of the present study, which uses this safe source of information sharing for study and research. In addition to this noble function, a medical record, when systematically well organized and complete, takes on a strategic value from the administrative, legal and academic viewpoints. All of these predicates could be observed in the records developed institutionally in UNIVAG and used in this study.

Despite the limitations of this study, in particular those related to secondary data collection, updates to the criteria over time, administrative actions such as changes in the forms implemented and memory bias associated with the independent variables, the availability of information over a long period of time enables the evaluation of trends regarding this relevant condition.

In the present study, of the 706 records evaluated, the prevalence of DDE in the first permanent molars in children 8 to 12 years of age was high (55.95\%), especially in teeth 36 and 46. In southern Brazil (Vargas-Ferreira et al., 2018), using the same age group, an even greater prevalence of enamel defects was found (64.0\%). A high prevalence was also found in a study conducted in Spain, with 52\% of the first permanent molars showing DDE. In a study conducted in Australia, $47 \%$ of children were affected by DDE; however, the upper molars were the most affected (Arrow, 2008; Robles et al., 2013). In contrast, in Poland, researchers who evaluated 475 children found a DDE prevalence of $9.6 \%$ in permanent dentition (Opydo-Szymaczeka et al., 2018). The presence of fluoride, the different criteria used for DDE classification, and the sample size are the main difficulties in comparing the prevalence data (Lo, Zheng \& King, 2003; Ryynanen et al., 2014).

Although DDE and MIH are pathologies frequently diagnosed in many populations worldwide, the aetiological factors remain inconsistent (Robles et al., 2013). A key feature of MIH is enamel defects of the first molars and incisors in permanent dentition (Weerheijm, Jalevik \& Alaluusua, 2001; Oliver et al., 2014). The technical difficulties in achieving analgesia and in managing difficult behaviours, the low enamel quality with unsatisfactory restorations, the failure of preventive measures and the limitations to the quality of life of patients with this condition justify the need for further studies on the aetiological factors of DDE (Arrow, 2008; Robles et al., 2013).

Previous publications corroborate the findings of this study regarding the lack of an association between DDE or MIH and sociodemographic characteristics (Lo, Zheng \& King, 2003; Vargas-Ferreira et al., 2018; Jacobsen et al., 2014; Tourino et al., 2016; Arrow, 2009; Wong et al., 2014). Although the differences in sex and DDE were not consistent, boys had a higher risk of hypomineralization than did girls (Wong et al., 2014). This may be due to the small number of individuals in the sample. Although no difference in the association of DDE with maternal education and with sex has been demonstrated in most studies, there is justification for DDE-related caries preventive and/or interventions in children younger than 8 years old, aiming to reduce the possibility of disseminating inflammation to the tooth germ of permanent teeth (Lo, Zheng \& King, 2003). In addition, enamel defects are more prevalent and extensive in younger children (Vargas-Ferreira et al., 2018).

Regarding the maternal factors evaluated in this study, only type of delivery (caesarean section, forceps or preterm delivery) was associated with DDE. This finding was corroborated by a study conducted in Australia in 2009, in which preterm delivery exhibited a statistically significant association with DDE (Arrow, 2008). These findings are in line with a systematic review conducted in 2016 (Silva et al., 2016), despite the limited number of studies selected, factors such as prematurity and complications during delivery were associated with MIH. However, multivariate analysis found no association between MIH 
and the use of medications to prevent complications at birth and preterm delivery (Tourino et al., 2016). Such discrepancies may have occurred because preterm infants may be more likely than full-term infants to have complications.

Although DDE and maternal factors, such as health status during pregnancy, did not show a strong association (Arrow, 2009; Wong et al., 2014), MIH was statistically significant among mothers who reported problems during pregnancy (Whatling \& Fearne; 2008). This result may be related to systemic changes, which likely act synergistically and may cause defects in the enamel. Individual or low-intensity factors may not cause the condition, but the simultaneous occurrence of 2 or more factors and at different intensities may result in enamel defects (Whatling \& Fearne; 2008). Acidosis and hypoxia due to prolonged labour or the health conditions of the mother leading to a caesarean section may explain the association with DDE (Pitiphat et al., 2014).

The literature shows that breastfeeding may be associated with DDE. Dioxin is a contaminant stored in body fat, and its concentration is easily measured in breast milk. As ameloblasts are susceptible to this contaminant, it can be a causative agent of DDE/MIH in children (Ngoc et al., 2018; Salmela et al., 2011; Jedeon et al., 2013). However, this study showed no association, most likely because most of the children breastfed for less than 6 months and DDE depends on the amount of contaminant available and a long breastfeeding duration (Wong et al., 2014; Hölttä et al., 2001; Laisi et al., 2008).

Systemic disease and hospitalization in the first to 3 years of life were associated with DDE of permanent molars, most likely related to the critical period of amelogenesis between 0 and 2 years of age, when a child is particularly vulnerable to systemic changes that can affect enamel development (Robles et al., 2013). Childhood diseases evidenced in this study, such as pneumonia, jaundice, malnutrition, anaemia, bronchitis, measles, reflux, seizures, dengue, fainting, chickenpox, hepatitis, cavernous haemangioma, diabetes, asthma, allergic rhinitis, and atopic dermatitis, in addition to fever were considered risk factors for DDE (Tourino et al., 2016; Silva et al., 2016; Arrow, 209; Edwards et al., 2006). The aetiology may be related to a metabolic disorder. In vitro studies have shown that high temperature $\left(39^{\circ} \mathrm{C}\right)$ can negatively affect regulator genes and hinder or delay the development of tooth enamel (Ryynanen et al., 2014). In addition, acidic conditions resulting in localized inflammation and hypoxia can prevent crystal growth due to the accumulation of hydrogen ions (Lo, Zheng \& King, 2003).

It was also evident from a prospective cohort study that children affected by severe diseases before age 3 are 7.89 times more likely to have DDE, but after adjusting for confounding factors, this association disappeared (Wong et al., 2014). This may be explained by the fact that the diseases were not evaluated separately. Childhood diseases during the period of tooth formation did not alter the prevalence of DDE, but DDE prevalence increased significantly in children with a history of severe disease. In addition, it was observed that a specific factor alone cannot be identified as the aetiological agent and that the simultaneous occurrence of 2 or more factors is necessary for DDE (Whatling \& Fearne, 2008).

Clinical and experimental studies suggest that enamel development defects (DDE and MIH) may result from a combined effect of systemic diseases (Silva et al., 2016), fever and the use of medications such as antibiotics (Tariq et al., 2014; Whatling \& Fearne, 2008), chemotherapy, and asthma, anti-epileptic, antiviral, antifungal and antiparasitic medications (Jacobsen et al., 2014). However, the interference of medications in amelogenesis is dose-dependent and varies according to the stage of life of the ameloblast at the time of exposure, and there is limited applicability of in vitro results in animal models to humans (Sahlberg et al., 2013; Serna et al., 2016). Corroborated by a previous study (Arrow, 2009), the use of medication in the first 3 years of life was not associated with DDE. Notably, it is not possible to determine whether the aetiology of DDE is medication or the disease because sick children are usually medicated (Whatling \& Fearne, 2008).

In the population studied, systemic diseases in the first 3 years of life were associated with DDE. Health problems affect the daily activities, well-being and self-esteem of people, with repercussions and consequences that can affect quality of life. Thus, it becomes important that knowledge and decisions about treatment be adequate, regardless of whether they are preventive, interceptive or related to clinical follow-up. 
Considering all the assertions and considerations outlined in the discussion and despite limitations in the present study as well as the observation of different prevalence rates and associations among studies in determining DDE risk, this study confirms the need for multiple and independent studies with more specific data collection, particularly focused on the causal factors and associations of this condition.

\section{Conclusion}

The association of DDE (hypomineralization/hypoplasia) in the first 4 permanent molars with the independent variables caesarean section, forceps or preterm delivery and systemic diseases in the first 3 years of life was statistically significant.

\section{References}

Arrow, P. (2008) Prevalence of developmental enamel defects of the first permanent molars among schoolchildren in Western Australia. Australian Dental Journal, 53: 250-259. 10.1111/j.1834-7819.2008.00057.x.

Arrow, P. (2009) Risk factors in the occurrence of enamel defects of the first permanent molars among schoolchildren in Western Australia. Community Dent Oral Epidemiol; 37: 405-415. 10.1111/j.1600-0528.2009.00480.x.

Edwards, M. J. (2006) Review: Hyperthermia and fever during pregnancy. Birth Defects Res A Clin Mol Teratol; 76 (7): $507-16.10 .1002 /$ bdra.20277.

FDI Commission on Oral Health. A review of the developmental defects of enamel index (DDE Index). Int Dent J. $1992 ; 42$ (6): $411-426$. PMID: 1286924.

Hölttä, P., Kiviranta, H., Leppäniemi, A., Vartiainen, T., Lukinmaa, P. L., \& Alaluusua, S. (2001) Developmental dental defects in children who reside by a river polluted by dioxins and furans. Arch Environ Health, 56 (6): 522-8. 10.1080/00039890109602901.

IBGE. Cidades. http://cidades.ibge.gov.br/xtras/perfil.php?lang=\&codmun=510840\&search=mato-grosso|varzea-grande, 2015.

Jacobsen, P. E., Haubek, D., Henriksen, T. B., Østergaard, J. R., \& Poulsen, S. (2014) Developmentalenamel defects in children born preterm: a systematic review. Eur J Oral Sci. 122: 7-14. 10.1111/eos.12094.

Jacobsen, P. E., Henriksen, T. B., Haubek, D., Østergaard, J. R., (2013) Developmental Enamel Defects in Children Prenatally Exposed to Anti-Epileptic Drugs. PLoS ONE, 8 (3): e 58213. 10.1371/ 0058213.

Jedeon, K., Dure-Molla, M. D. L., Brookes, S. J., Loiodice, S., Marciano, C., Kirkham, J., Canivenc-Lavier, M. C., Boudalia, S., Bergès, R., Harada, H., Berdal, A., \& Babajko, S. (2013) Enamel Defects Reflect Perinatal Exposure to Bisphenol A. The American Journal of Pathology, 183 (1): 108-118. 10.1016/j.ajpath.2013.04.004.

Jeremias, F., Pierri, R. A. G., Souza, J. F., Fragelli, C. M. B., Restrepo, M., Finoti, L. S., Bussaneli, D. G., Cordeiro, R. C. L., Secolin, R., Maurer-Morelli, C. V., Scarel-Caminaga R. M., \& Santos-Pinto, L. (2016) Family-Based Genetic Association for Molar-Incisor Hypomineralization. Caries Res, 50: 310-318. $10.1159 / 000445726$.

Laisi, S., Kiviranta, H., Lukinmaa, P. L., Vartiainen, T., \& Alaluusua, S. (2008) Molar-incisor-hypomineralisation and dioxins: new findings. Eur Arch Paediatr Dent, 9 (4): 224-227.

Lo, E. C. M., Zheng, C. G., \& King, N. M. (2003) Relationship between the Presence of Demarcated Opacities and Hypoplasia in Permanent Teeth and Caries in Their Primary Predecessors. Caries Res, 37, 456-461: 10.1159/000073400.

Ngoc, V. T. N., Huong, L. T, Nhon, B. V., Tan, N. T. M., Thuc, P. V., Hien, V. T. T., Dung, T. M., Toan, N. V., Le Quynh Anh, L. Q., Son, L. H., Chu-Dinh, T., \& Chu, D. T. (2018) The higher prevalence of developmental defects of enamel in the dioxin-affected region than non-dioxin-affected region: result from a cross-sectional study in Vietnam. The Society of The Nippon Dental University. Odontology. 10.1007/s10266-018-0358-1.

Oliver, K., Messer, L. B., Manton, D. J., Kan, K., Ng, F., Olsen, C., Sheahan, J., Silva, M., \& Chawla, N. (2014) Distribution and severity of molar hypomineralisation: trial of a new severity index. Int J Paediatr Dent, 24 (2): 131-51. 10.1111/ipd.12040.

Opydo-Szymaczeka, J., Gerreth, K., Borysewicz-Lewicka, M., Pawlaczyk-Kamieńska, T., Torlińska-Walkowiak, N., Śniatała, R. (2018) Enamel defects and dental caries among children attending primary schools in Poznań, Poland. Adv Clin Exp Med. 27 (11): 1535-1540. 10.17219/acem/73794.

Pitiphat, W., Luangchaichaweng, S., Pungchanchaikul, P., Angwaravong, O., \& Chansamak, N. (2014) Factors associated with molar incisor hypomineralization in Thai children. Eur J Oral Sci, 122: 265-270. 10.1111/eos.12136.

Robles, M. J., Ruiz, M., Bravo-Perez, M., González, E., \& Peñalver, M. A. (2013) Prevalence of enamel defects in primary and permanent teeth in a group of schoolchildren from Granada (Spain). Med Oral Patol Oral Cir Bucal. 18 (2): 187-93. 0.1016/j.archoralbio.2014.01.005.

Ryynanen, H., Sahlberg, C., Lukinmaa ,P-L., \& Alaluusua, S.. (2014) The effect of high temperature on the development of mouse dental enamel in vitro. Arch Oral Biol, 59: 400-6.

Sahlberg. C., Pavlic, A., Ess, A., Lukinmaa, P. L., Salmela, E., \& Alaluusua, S. (2013) Combined effect of amoxicillin and sodium fluoride on the structure of developing mouse enamel in vitro. Archives of Oral Biology, 58 (9): 1155-64. 10.1016/j.archoralbio.2013.03.007. 
Salmela, E., Lukinmaa, P. L., Partanen, A. M., Sahlberg, C., \& Alaluusua, S. (2011) Combined effect of fluoride and 2,3,7,8-tetrachlorodibenzo-p-dioxin on mouse dental hard tissue formation in vitro. Arch Toxicol. 85: 953-963. 10.1007/s00204-010-0619-4.

Serna, C., Vicente, A., Finke, C., \& Ortiz, A. J. (2016) Drugs related to the etiology of molar incisor hypomineralization - A systematic review. JADA, 147 (2): 120-130. 10.1016/j.adaj.2015.08.011.

Silva, M. J., Scurrah, K. J., Craig, J. M., Manton, D.J., Kilpatrick, N. (2016) Etiology of molar incisor hypomineralization - A systematic review. Community Dent Oral Epidemiol, 44 (4): 342-53. 10.1111/cdoe.12229.

Tariq, A., Ansari, M. A., Ismail, M. O., Memon, Z. (2014) Association of the use of bacterial cell wall synthesis Inhibitor drugs in early childhood with the Developmental Defects of Enamel. Pak J Med Sci. 30 (2): 393-397.

Tourino, L. F. P. G., Corrêa-Faria, P., Ferreira, R. C., Bendo, C. B., Zarzar, P. M., \& Vale, M. P. (2016) Association between Molar Incisor Hypomineralization in Schoolchildren and Both Prenatal and Postnatal Factors: A Population-Based Study. PLoS ONE. 11 (6): e 0156332. 10.1371/journal.pone.0156332.

Vargas-Ferreira F, Peres, M. A., Dumith, S. C., Thomson, W. M., Demaco, F. F., (2018) Association of Pre- Peri- and Postnatal Factors with Developmental Defects of Enamel in Schoolchildren.J Clin Pediatr Dent. 42 (2):125-134. 10.17796/1053-4628-42.2.8.

Weerheijm, K, L, Jalevikmm B., \& Alaluusua, S. (2001) Molar-Incisor Hypomineralisation. Caries Res, 35: 390-391. 10.1159/000047479.

Whatling, R., \& Fearne, J. M. (2008) Molar incisor hypomineralization: a study of a etiological factors in a group of UK children. Int J Paediatr Dent. 18: 155162. 10.1111/j.1365-263X.2007.00901.x.

Wong, H. M., Peng, S-M., Wen, Y. F., King, N. M., McGrath, C. P. J. (2014) Risk Factors of Developmental Defects of Enamel-A Prospective Cohort Study. PLoS ONE. 9 (10): e109351. 10.1371/journal.pone.0109351. 